\title{
Microstructure and plasma resistance of $\mathrm{Y}_{2} \mathrm{O}_{3}-\mathrm{BN}$ composites
}

\author{
Hyun-Kyu Lee, Seokshin Lee*, Bi-Ryong Kim, Tae-Eon Park** and Young-Hoon Yun***,† \\ Dept. of New Material Engineering, Chosun University, Gwangju 501-759, Korea \\ *Dept. of Mechanical Engineering, Chosun University, Gwangju 501-759, Korea \\ **Ecotechkorea Co., LTD, Jeonnam Advanced Ceramics Center, Mokpo 530-370, Korea \\ ***Dept. of Hydrogen \& Fuel Cell Tech., Dongshin University, Naju 520-714, Korea
}

(Received June 3, 2014)

(Revised June 16, 2014)

(Accepted June 18, 2014)

Abstract $\mathrm{Y}_{2} \mathrm{O}_{3}$-BN ceramic composites were fabricated from the slurries of yttria powder with average particle size of $3 \sim 10 \mu \mathrm{m}$. The slurry was fabricated by mixing PVA binder, $\mathrm{NaOH}$ for $\mathrm{Ph}$ control, PEG, BN powder and $\mathrm{Y}_{2} \mathrm{O}_{3}$ powder. The mixed $\mathrm{Y}_{2} \mathrm{O}_{3}$ powders were obtained by spray drying process from the slurry. The $\mathrm{Y}_{2} \mathrm{O}_{3}-\mathrm{BN}$ composite specimen was shaped in size of $\varnothing 14 \mathrm{~mm}$ and then sintered at $1550^{\circ} \mathrm{C}$ and $1600^{\circ} \mathrm{C}$, respectively. The characteristics, microstructure, purities, densities, bulk resistance, thermal expansion, hardness and plasma resistance of the $\mathrm{Y}_{2} \mathrm{O}_{3}$ - $\mathrm{BN}$ composites were investigated with the function of $\mathrm{BN}$ contents and sintering temperature.

Key words Yttria $\left(\mathrm{Y}_{2} \mathrm{O}_{3}\right)$, Plasma resistance, Composites, Microstructure

\section{$\mathrm{Y}_{2} \mathrm{O}_{3}-\mathrm{BN}$ 복합체의 미세구조 및 내플라즈마 특성}

이현규, 이석신*, 김비룡, 박태언**, 윤영훈***,†

조선대학교 신소재공학과, 광주, 501-759

*조선대학교 기계공학과, 광주, $501-759$

**(주)에코텍코리아, 세라믹종합지원센터, 목포, 530-370

***동신대학교 수소에너지학과, 나주, 520-714

(2014년 6월 3일 접수)

(2014년 6월 16일 심사완료)

(2014년 6월 18일 게재확정)

요 약 $\mathrm{Y}_{2} \mathrm{O}_{3}-\mathrm{BN}$ 세라믹 복합체를 제작하기 위해서, 분말 입도 $3 \sim 10 \mu \mathrm{m}$ 인 $\mathrm{Y}_{2} \mathrm{O}_{3}$ 분말을 분산한 슬러리에 $\mathrm{pH}$ 조절제인 $\mathrm{NaOH}$ 를 첨가하였으며 결합제로는 $\mathrm{PVA}$, 가소제로는 $\mathrm{PEG}$ 를, $\mathrm{BN}$ 분말과 혼합하고, 분무건조(spray drying)공정을 거쳐 $\mathrm{Y}_{2} \mathrm{O}_{3}$ 혼합 분말을 제조하였다. $\varnothing 14 \mathrm{~mm}$ 크기의 $\mathrm{Y}_{2} \mathrm{O}_{3}-\mathrm{BN}$ 시편을 성형하고, $1550^{\circ} \mathrm{C}$ 및 $1600^{\circ} \mathrm{C}$ 에서 소결하여 $\mathrm{Y}_{2} \mathrm{O}_{3}-\mathrm{BN}$ 복합체를 제작하였다. $\mathrm{BN}$ 투입량과 소결온도의 변수에 따른 미세구조, 순도, 꺽임강도, 열팽창계수, 밀도, 체적저항, 내플라즈마 특성 을 조사하였다.

\section{1. 서}

최근 급속한 IT산업의 발전으로 고순도 세라믹소재의 수요가 빠르게 증가하고 있다. 특히 반도체 및 LED 산 업의 급성장으로 인하여 디바이스를 제조하는 장비에 사 용되는 세라믹 제품의 중요성이 더욱 부각되고 있다.

\footnotetext{
Corresponding author

Tel: +82-61-330-3234

Fax: +82-61-330-2909

E-mail:yunh2@dsu.ac.kr
}

반도체 산업에서 대두되고 있는 핵심적인 기술은 선폭 의 미세화와 고집적이며, 이를 위해서 플라즈마 에칭기 술, $\mathrm{CVD}$ 코팅 기술 등 반도체 제조 공정의 장비를 활용 하게 된다[1]. 반도체 제조용 공정장비 $(\mathrm{CVD}, \mathrm{Etch})$ 는 다 양한 플라즈마를 활용하므로, 이들 장비에 사용되는 부 품들은 내플라즈마 특성이 우수한 재료를 사용해야 한다 [2-5]. 현재까지는 내플라즈마성 소재로서 $\mathrm{Al}_{2} \mathrm{O}_{3}$ 가 주로 사용되고 있으나 오염입자의 저감 및 관리가 엄격한 공정 에서는 일부 $\mathrm{Y}_{2} \mathrm{O}_{3}$ 및 $\mathrm{AIN}$ 소재로 교체되는 부품이 점점 늘어나는 추세이다. $300 \mathrm{~mm}$ 웨이퍼공정 및 $450 \mathrm{~mm}$ 웨이 
퍼 공정에서는 제품의 수율향상을 위해서 고밀도 플라즈 마의 활용이 증가하면서 장비 부품으로부터 발생되는 오 염입자를 최소화할 수 있거나, 내플라즈마성이 우수하고, 오염입자의 포집력이 있는 소재의 사용이 요구된다[6].

특히 반도체 기술의 발달과 함께 내플라즈마 특성이 우수한 $\mathrm{Y}_{2} \mathrm{O}_{3}$ 소재에 대한 관심은 더욱 높아졌으며 향후 핵심 소재로 부각될 것으로 기대된다. 현재 일반적으로 사용되고 있는 $\mathrm{Al}_{2} \mathrm{O}_{3}$ 소재에 비해, $\mathrm{Y}_{2} \mathrm{O}_{3}$ 제품은 원료를 모두 수입에 의존하고 있어 $\mathrm{Al}_{2} \mathrm{O}_{3}$ 대비, 약 $5 \sim 10$ 배 이 상 고가이므로, 우수한 내플라즈마 특성에도 불구하고 제한적으로 활용되고 있다. 또한 비교적 가격이 저렴한 용사 코팅을 이용하여 사용되는 제품이 많다[7]. 하지만 코팅제품은 모제와 $\mathrm{Y}_{2} \mathrm{O}_{3}$ 의 열팽창계수 차에 의한 코팅 막의 박리 등으로 수명이 짧아 재코팅 해서 사용해야하 는 문제점과, 코팅시 재료의 부착율은 $15 \sim 20 \%$ 로 낮고 소재에도 기공이 다량 존재하여 $\mathrm{Y}_{2} \mathrm{O}_{3}$ 소재의 성능 향상 에 한계가 있다. 따라서, $\mathrm{Y}_{2} \mathrm{O}_{3}$ 소재 개선을 위해 다양한 연구들이 진행되어 왔다. $\mathrm{Y}_{2} \mathrm{O}_{3}$ 의 소결 조제로써 $\mathrm{Zr}, \mathrm{Si}$, $\mathrm{Ce}, \mathrm{Al}$ 중 한 가지 이상을 첨가하여 $\mathrm{Y}_{2} \mathrm{O}_{3}$ 복합체를 제 조하는 연구가 있었으나 이는 플라즈마 내성이 저하되는 요인이 되고, 이는 유전손실을 일으킨다.

소결밀도를 개선하기 위해 첨가제로 $\mathrm{Ti}\left(\mathrm{TiO}_{2}\right)$ 를 첨가 하고 있지만 $\mathrm{Ti}$ 함유량이 증대되면 플라즈마 내성이 저 하되는 경향이 보고되고 있다[8]. 또한 $\mathrm{Y}_{2} \mathrm{O}_{3}$ 이외에 내 플라즈마성이 우수한 재료인 $\mathrm{AlN}$ 에 $\mathrm{Y}_{2} \mathrm{O}_{3}$ 와 $\mathrm{MgO}$ 또는 $\mathrm{Mg}_{3} \mathrm{~N}_{2}$ 를 첨가하는 방법이 연구되었는데, 이는 정밀한 조건 제어가 필요하다는 단점이 지적되고 있다. $\mathrm{Y}_{2} \mathrm{O}_{3}$ 세라믹스의 우수한 특성을 유지하고, 입성장에 의한 기 계적 물성 저하를 방지하기 위해 저온에서 소결하는 연 구들이 보고되었다[9-11]. $\mathrm{Y}_{2} \mathrm{O}_{3}$ 의 소결온도 및 소결시간 을 단축시키면서, 내플라즈마 특성을 유지하기 위해, $\mathrm{Al}_{2} \mathrm{O}_{3}, \mathrm{ZrO}_{2}, \mathrm{BN}$ 등과 같이 플라즈마에 의해 활성화된 라디칼에 대해 양이온저항성이 우수한 소재를 도입하여 복합체를 제작하는 연구가 보고되었다[12-15].

본 연구에서는 $\mathrm{Y}_{2} \mathrm{O}_{3}$ 원료에 $\mathrm{BN}$ 을 첨가하여, $\mathrm{Y}_{2} \mathrm{O}_{3}$ 의 소결온도 및 소결시간을 단축하기 위해, $\mathrm{Y}_{2} \mathrm{O}_{3}-\mathrm{BN}$ 복합 체를 제작하고, 미세구조 및 밀도, 꺽임강도, 플라즈마 저항성 등을 조사하고자 한다.

\section{2. 실험방법}

\section{1. $\mathrm{BN}$ 을 첨가한 $\mathrm{Y}_{2} \mathrm{O}_{3}$ 혼합 분말의 합성}

\subsection{1. 혼합분말의 제조}

본 연구에서는 $\mathrm{Y}_{2} \mathrm{O}_{3}$ 원료 분말(CZC-ZL China)을 사 용하였다. 원료분말의 특성은 순도 $99.99 \%$, 분말 입도
는 3 10 $\mu \mathrm{m}$ 영역을 나타내었다. $\mathrm{Y}_{2} \mathrm{O}_{3}$ 분말을 DI water 에 분산한 후 볼밀(ball mill)을 통해 1 차 분쇄 후 필터 링한 슬러리에 바인더, 가소제, 소포제, $\mathrm{pH}$ 조절제 등 첨가제를 넣은 후 attrition milling을 통해 혼합하여 분 무과립용 슬러리를 제조하였다. Milling media로서 $\mathrm{ZrO}_{2}$ ball을 사용하였다. 열분무 건조기(FOC-20, Disc type, Ohkawara)를 이용하여 입구온도 $180^{\circ} \mathrm{C}$, 출구온도 $110^{\circ} \mathrm{C}$, $\mathrm{RPM} 4,000$, feeding rate $10 \mathrm{~L} / \mathrm{hr}$ 의 조건에서 열분무 건 조를 행하였다.

\subsection{2. 혼합분말의 분석}

시험조건에 따른 슬러리 특성을 분석하기 위하여 milling media로 직경 $5 \mathrm{~mm}, 10 \mathrm{~mm} \mathrm{ZrO}$ ball을 폴리프로필렌 병 용적의 $50 \%$ 를 채워 고형분량을 $20 \mathrm{vol} \%$ 혼합하였으 며, 분산용매로 DI water를 사용하였다. 분말의 분산 및 응집을 위한 최종 $\mathrm{pH}$ 조절제로 강염기인 $\mathrm{NaOH}$ 를 사용 하였다. $\mathrm{pH}$ 조절제를 첨가하여 Viscometer(BrookfieldII, USA)로 점도를 측정하였다. 슬러리의 분산특성은 Zeta Potential Analyzer(ZetaPALS, BrookHaven, USA)를 이 용하여 측정하였다. 전해질 수용액은 $10 \mathrm{~mol} / \mathrm{L}$ 농도의 buffer재인 질산암모늄 $\left(\mathrm{NH}_{4} \mathrm{NO}_{3}\right)$ 을 사용하였다.

\section{2. $\mathrm{Y}_{2} \mathrm{O}_{3}-\mathrm{BN}$ 복합체 제작}

\subsection{1. 성형체 제작 및 소결}

$\mathrm{Y}_{2} \mathrm{O}_{3}$ - $\mathrm{BN}$ 복합체의 특성을 분석하기 위해, $\mathrm{Y}_{2} \mathrm{O}_{3}$ 에 $\mathrm{BN}$ 을 $0.25 \mathrm{wt} \%, 0.5 \mathrm{wt} \%, 1 \mathrm{wt} \%, 2 \mathrm{wt} \%$ 씩 혼합시킨 후, 분 무건조기를 이용하여 과립화하였다. 각 조성의 밀도, 순 도, 꺽임강도, 절연저항, 열팽창계수, 비커스 경도 등의 특성분석을 위한 시험편 $\varnothing 14 \mathrm{~mm}$ 인 원형몰드를 사용하 여 건식 압축가압성형법으로 $1,500 \mathrm{kgf} / \mathrm{cm}^{2}$ 압력 하에 제 작하였고, 소성하였다. 소성은 전기로에서, 각각 $1,550^{\circ} \mathrm{C}$, $1,600^{\circ} \mathrm{C}$ 까지 승온시킨 후, 4 시간 유지하는 조건으로 제작 하였다.

\subsection{2. 특성 분석}

Y2O3-BN 복합체의 밀도는 Gas-pycnometer(G PYC100-A, PMI, USA), 비커스 경도는 Vikers Hardness Tester(VMT-7, Matsuzawa, Japan), 열팽창계수 측정은 Dilatometer(Dilatronic, Theta, USA), 순도측정은 ICPMS(OPTIMA DCRII, Perkin elmer's, USA), 꺽임강도 는 굽힘강도 시험기(4206, INSTRON, USA) 절연저항 측정은 Megger(8104 OMNIA, Associated Research, USA)로 측정 하였다. 미세구조는 Scanning Electron Microscope(JSM-5900, JEOL, Japan)을 이용하여 관찰하 였다. 결정상 분석은 X-ray diffraction(Rotarflex, Rigaku, Japan) 분석을 통해 이루어졌다. 
Table 1

Viscosities of the slurries of with $\mathrm{NaOH}$ content

\begin{tabular}{llllll}
\hline \multicolumn{5}{l}{$\mathrm{NaOH}$ content } \\
\cline { 2 - 6 } & $0.00 \%$ & $0.01 \%$ & $0.03 \%$ & $0.05 \%$ & $0.07 \%$ \\
\hline Viscosity & $130 \mathrm{cps}$ & $434 \mathrm{cps}$ & $530 \mathrm{cps}$ & $660 \mathrm{cps}$ & $710 \mathrm{cps}$ \\
\hline
\end{tabular}

\section{3. 결과 및 고찰}

\section{1. $\mathrm{Y}_{2} \mathrm{O}_{3}-\mathrm{BN}$ 혼합분말의 특성}

$\mathrm{Y}_{2} \mathrm{O}_{3} / \mathrm{BN}$ 이 혼합된 슬러리에 대해 측정된 Zeta-potential 을 기준하여, 염기적정액인 $\mathrm{NaOH} 10 \%$ solution을 이 용하여 분말 무게비로 첨가하여 다시 ball milling한 후, 점도 측정한 결과 염기성 적정액인 $\mathrm{NaOH}$ 를 첨가하지 않았을 경우, $130 \mathrm{cps}$ 의 낮은 점도값을 나타내었고, $\mathrm{NaOH}$ 첨가량이 증가할수록 점도가 증가하였다(Table 1).

$\mathrm{NaOH}$ 가 첨가되지 않은 슬러리 $(\mathrm{pH}$ 7)의 경우 분무건조 시, 도넛형태의 과립이 제조되었으며 $\mathrm{NaOH}$ 첨가량이 증가할수록, 중공상 과립을 형성하다가 $\mathrm{NaOH}$ 첨가량이 $0.05 \%$ 인 조건에서 구형의 과립이 제조되었다(Fig. 1). 중공상의 구형 과립의 형성은 Table 1 에 나타낸 것과 같이, $\mathrm{NaOH}$ 첨가에 의한 점도 증가와 연관되는 것으로 추정되었다.

$\mathrm{Y}_{2} \mathrm{O}_{3}$ 과립을 이용하여 성형 시 입자간 결합이 용이하게 하기 위해서 결합제 $\mathrm{PVA}$ 를 활용하였다. 본 연구에서는 결 합제 첨가량에 따른 성형 시 과립의 파괴양상을 알아보기 위하여 성형밀도, 성형체의 파단면을 관찰하였다(Fig. 2).

바인더, $\mathrm{PVA}$ 의 경우 첨가량을 $0.5 \% \sim 1.25 \%$ 범위에 서 변화시킬 때, 분무 과립을 형성한 경우, 첨가량에 따 른 과립형상의 변화는 나타나지 않았다. $1,000 \mathrm{kgf} / \mathrm{cm}^{2}$ 의 압력으로 시험편을 제작하여, 성형체의 표면과 성형체의 파단면을 관찰한 결과 결합제가 $0.5 \mathrm{wt} \%$ 첨가될 때, 성 형체의 표면에 과립 형상을 찾아 볼 수 없었고, 파단면 의 미세구조관찰에서 과립이 파괴되는 경향을 나타내었 다(Fig. 2). 결합제 함량이 $1.0 \mathrm{wt} \%$ 일 경우 성형체의 표
Table 2

Relative density of green specimens and sintered specimens with PVA contents (Forming pressure: 1,000 kgf/ $\mathrm{cm}^{2}$, Sintering temperature: $1650^{\circ} \mathrm{C}, 20 \mathrm{hrs}$ )

\begin{tabular}{lllll}
\hline & \multicolumn{3}{l}{ PVA content } & \\
\cline { 2 - 5 } & $0.5 \mathrm{wt} \%$ & $0.75 \mathrm{wt} \%$ & $1.0 \mathrm{wt} \%$ & $1.25 \mathrm{wt} \%$ \\
\hline Green specimens & $2.64 \mathrm{~g} / \mathrm{cm}^{3}$ & $2.60 \mathrm{~g} / \mathrm{cm}^{3}$ & $2.60 \mathrm{~g} / \mathrm{cm}^{3}$ & $2.58 \mathrm{~g} / \mathrm{cm}^{3}$ \\
& $52.41 \%$ & $51.65 \%$ & $51.73 \%$ & $51.20 \%$ \\
Sintered specimens & $4.94 \mathrm{~g} / \mathrm{cm}^{3}$ & $4.96 \mathrm{~g} / \mathrm{cm}^{3}$ & $4.91 \mathrm{~g} / \mathrm{cm}^{3}$ & $4.90 \mathrm{~g} / \mathrm{cm}^{3}$ \\
& $98.29 \%$ & $98.56 \%$ & $97.40 \%$ & $98.54 \%$ \\
\hline
\end{tabular}

Table 3

Relative density of green specimens and sintered specimens with PEG contents (Forming pressure: $1,000 \mathrm{kgf} / \mathrm{cm}^{2}$, Sintering temperature: $1650^{\circ} \mathrm{C}, 30 \mathrm{hrs}$ )

\begin{tabular}{lllll}
\hline & PEG & & & \\
\cline { 2 - 5 } & $0.0 \mathrm{wt} \%$ & $0.25 \mathrm{wt} \%$ & $0.5 \mathrm{wt} \%$ & $0.75 \mathrm{wt} \%$ \\
\hline Green specimens & $2.56 \mathrm{~g} / \mathrm{cm}^{3}$ & $2.57 \mathrm{~g} / \mathrm{cm}^{3}$ & $2.62 \mathrm{~g} / \mathrm{cm}^{3}$ & $2.62 \mathrm{~g} / \mathrm{cm}^{3}$ \\
& $50.82 \%$ & $51.14 \%$ & $52.0 \%$ & $52.0 \%$ \\
Sintered specimens & $4.94 \mathrm{~g} / \mathrm{cm}^{3}$ & $4.93 \mathrm{~g} / \mathrm{cm}^{3}$ & $4.95 \mathrm{~g} / \mathrm{cm}^{3}$ & $4.96 \mathrm{~g} / \mathrm{cm}^{3}$ \\
& $98.14 \%$ & $98.09 \%$ & $98.44 \%$ & $98.60 \%$ \\
\hline
\end{tabular}

면에 과립의 경계면이 관찰되었다. 성형체의 파단면을 관찰에서, 성형체의 내부는 완전히 파괴되는 것이 관찰 되었다. 결합제 함량이 $1.25 \mathrm{wt} \%$ 일 경우는 성형체의 표 면 뿐만 아니라 성형체 파단면에서도 과립이 파괴되지 않은 것이 명확히 관찰되었다. 과립의 파괴가 이루어지 지 않는 성형체의 경우, 소결 시 과립간 기공 및 조대한 입자들로 구성된 미세구조를 나타냈고, 큰 폐기공과 더 불어 낮은 소결밀도를 나타내었다(Table 2).

본 연구에서는 유리전이온도 $(\mathrm{Tg})$ 를 낮추기 위해 PEG 첨가량을 조절하여 제조한 과립분말을 사용하여, 가압 성형시 과립의 성형밀도, 소결 후 소결밀도를 분석하여, 최적의 $\mathrm{PEG}$ 함량을 도출하기 위해 $\mathrm{PEG}$ 함량에 따른 특성을 분석하였다. Table 3 에 PEG 함량을 $0 \% \sim 0.75 \%$ 로 변화하여 제조한 과립의 성형 밀도 및 소결밀도 값 을 나타내었다. PEG 함량이 높아질수록 성형밀도가 다소

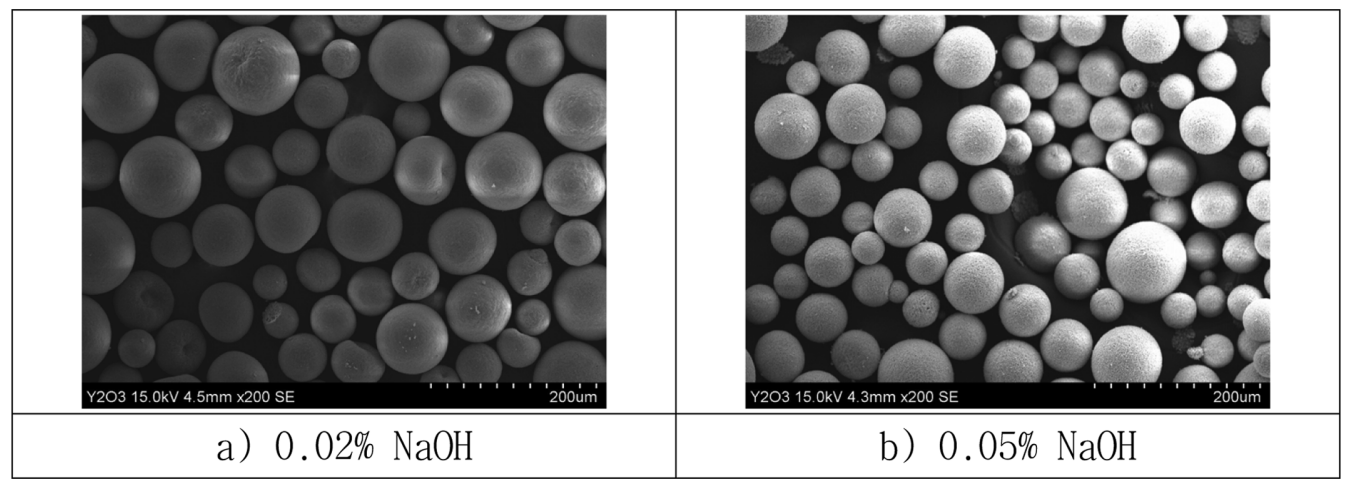

Fig. 1. Microstructure of the mixed powder with $\mathrm{NaOH}$ content. 


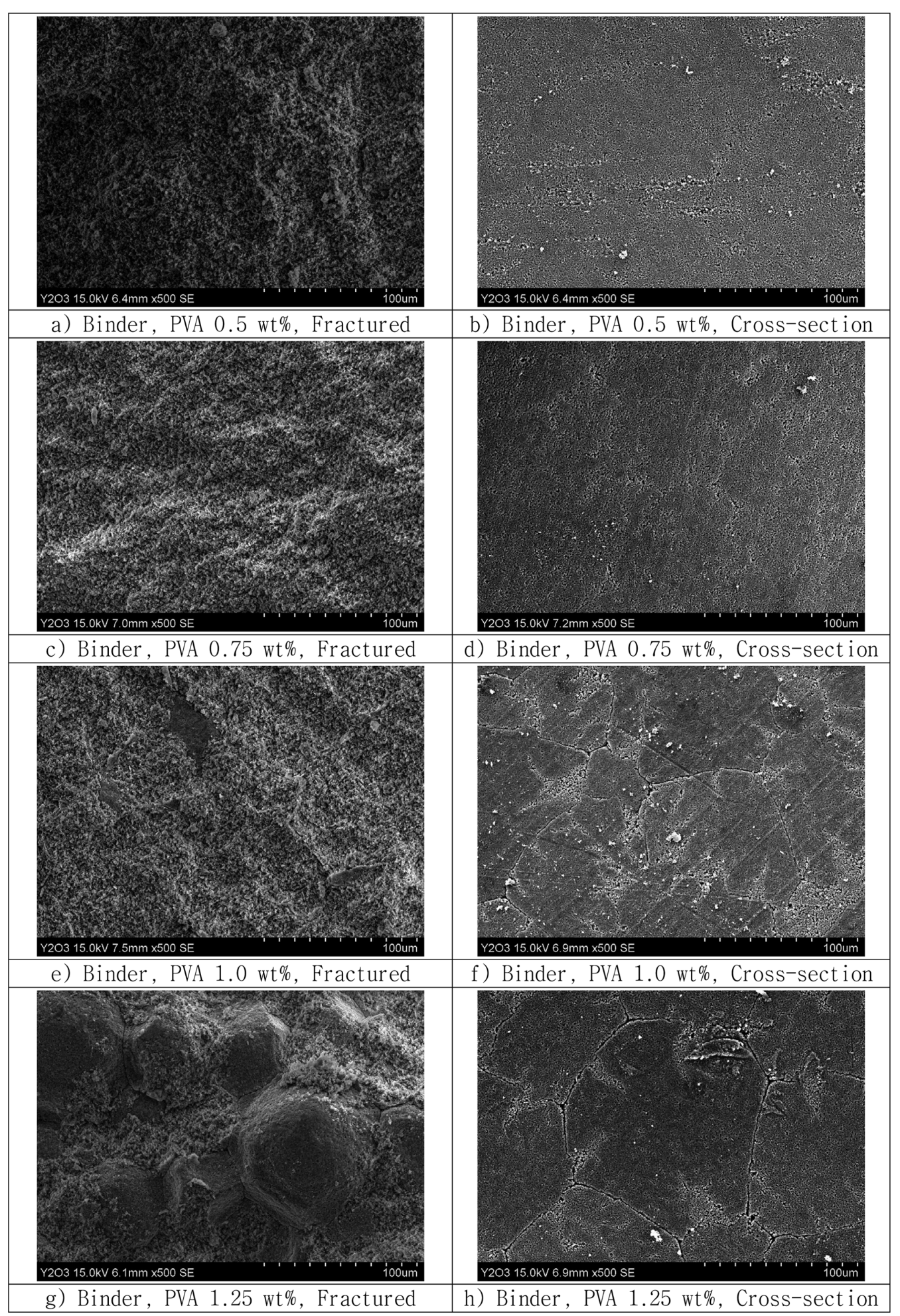

Fig. 2. Microstructure of green specimens with PVA contents (Forming pressure: $1,000 \mathrm{kgf} / \mathrm{cm}^{2}$ ).

증가하였으며 소결밀도는 거의 비슷한 경향을 나타냈다.

\section{2. $\mathrm{Y}_{2} \mathrm{O}_{3}-\mathrm{BN}$ 복합체의 특성 및 플라즈마 저항성}

Table 4는 BN 함량을 조절하여 제조한 과립을 성형압
력 $1,500 \mathrm{kgf} / \mathrm{cm}^{2}$ 의 압력으로 성형한 후 $1,550^{\circ} \mathrm{C}$ 에서 4 시 간 소결하여 제조한 시편을 측정한 물성표를 나타내었다. $\mathrm{BN}$ 함량이 $0.25-0.5 \mathrm{wt} \%$ 의 조건에서 비교적 높은 꺾임강 도 및 경도를 나타내었으며, $\mathrm{BN}$ 첨가량이 증가하면서 꺽 임강도와 경도 값이 다소 감소되는 경향을 나타내었다. 
Table 4

Characteristics of $\mathrm{Y}_{2} \mathrm{O}_{3}-\mathrm{BN}$ composites $\left(1,550^{\circ} \mathrm{C}, 4 \mathrm{hrs}\right)$

\begin{tabular}{llllll}
\hline & $\mathrm{Y}_{2} \mathrm{O}_{3}$-BN composites & $\mathrm{BN}-0.25 \%$ & $\mathrm{BN}-0.5 \%$ & $\mathrm{BN}-1 \%$ & $\mathrm{BN}-2 \%$ \\
\hline Purity & $\%$ & 99.17 & 98.71 & 98.64 & 97.50 \\
Density & $\mathrm{g} / \mathrm{cm}^{3}$ & 4.90 & 4.90 & 4.88 & 4.87 \\
Flexural strength & $\mathrm{Mpa}$ & 141 & 137 & 130 & 125 \\
Resistance & $\Omega \cdot \mathrm{Cm}$ & $5.71 * 10^{15}$ & $6.31 * 10^{14}$ & $4.78^{*} 10^{13}$ & $3.61 * 10^{13}$ \\
Thermal expansion & $10^{-6} / \mathrm{K}$ & 8.15 & 8.31 & 8.47 & 8.76 \\
Vikers Hardness & $\mathrm{Hv}$ & 671 & 659 & 612 & 597 \\
\hline
\end{tabular}

Table 5

Characteristics of $\mathrm{Y}_{2} \mathrm{O}_{3}$-BN composites $\left(1,600^{\circ} \mathrm{C}, 4 \mathrm{hrs}\right)$

\begin{tabular}{llllll}
\hline & $\mathrm{Y}_{2} \mathrm{O}_{3}$-BN composites & $\mathrm{BN}-0.25 \%$ & $\mathrm{BN}-0.5 \%$ & $\mathrm{BN}-1 \%$ & $\mathrm{BN}-2 \%$ \\
\hline Purity & $\%$ & 99.46 & 98.51 & 98.17 & 97.49 \\
Density & $\mathrm{g} / \mathrm{cm}^{3}$ & 4.91 & 4.90 & 4.89 & 4.86 \\
Flexural strength & $\mathrm{Mpa}$ & 145 & 140 & 132 & 129 \\
Resistance & $\Omega \cdot \mathrm{Cm}$ & $5.51^{*} 10^{15}$ & $6.67 * 10^{14}$ & $4.60 * 10^{13}$ & $3.76^{*} 10^{13}$ \\
Thermal expansion & $10^{-6} / \mathrm{K}$ & 8.04 & 8.17 & 8.29 & 8.55 \\
Vikers Hardness & $\mathrm{Hv}$ & 689 & 667 & 631 & 603 \\
\hline
\end{tabular}

Table 5에 $\mathrm{BN}$ 함량을 조절하여 제조한 과립을 성형압 력 $1,500 \mathrm{kgf} / \mathrm{cm}^{2}$ 의 압력으로 성형한 후 $1,600^{\circ} \mathrm{C}$ 에서 4 시 간 소결하여 제조한 시편을 측정한 물성표를 나타내었다.

$1,600^{\circ} \mathrm{C}$ 의 소결온도 조건에서, $\mathrm{BN} 0.25 \mathrm{wt} \%$ 첨가하여 제작된 복합체 시편이 비교적 높은 꺽임강도 및 경도 값 을 나타내었다. $\mathrm{BN}$ 첨가량이 많아짐에 따라 비커스경도, 꺽임강도, 절연저항 등 물성이 낮아지는 결과를 나타내 었다. $1,500^{\circ} \mathrm{C}$ 에서 $1600^{\circ} \mathrm{C}$ 로 소결온도가 높아짐에 따라 밀도가 다소 증가하는 경향을 나타내었다.

Fig. 3의 $\mathrm{XRD}$ pattern에서 $\mathrm{BN}$ 이 미량 첨가된 $\mathrm{Y}_{2} \mathrm{O}_{3}$ 복합체는 일반적인 $\mathrm{Y}_{2} \mathrm{O}_{3}$ 소결체는 유사한 패턴을 나타 냈다. 밀도는 $4.9 \mathrm{~g} / \mathrm{cm}^{3}$ 내외이며 체적저항, 비커스 경도, 꺽임강도 및 열팽창계수 모두 고순도 $\mathrm{Y}_{2} \mathrm{O}_{3}$ 와 유사한 결 과값을 나타냈다.

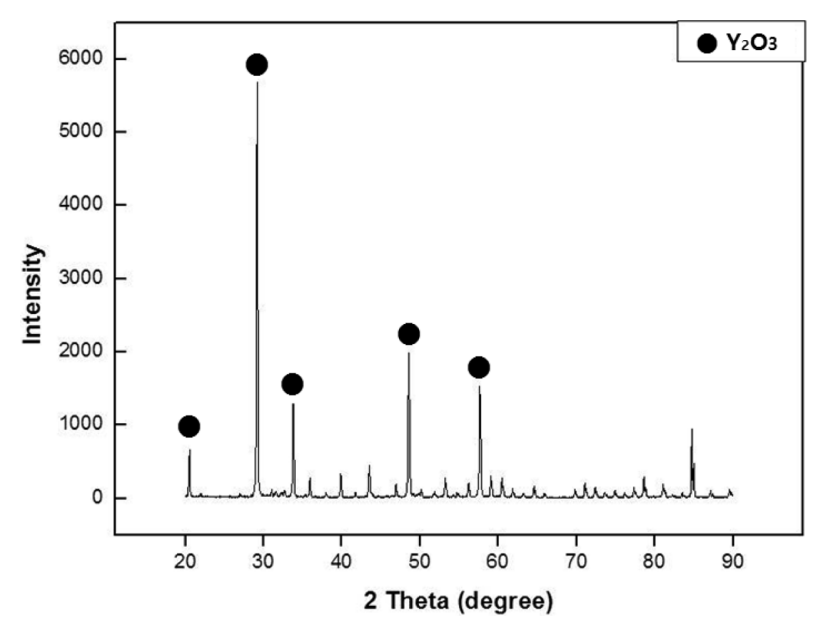

Fig. 3. XRD pattern of $\mathrm{Y}_{2} \mathrm{O}_{3}-0.25 \mathrm{wt} \% \mathrm{BN}$ composites.
Fig. 4에서 관찰된 바와 같이 입자성장이 진행된 경우, 입자이탈의 문제가 발생하고, 내플라즈마성이 저하되지 만, 미세구조 관찰에서 나타난 것과 같이 대체로 $20 \mu \mathrm{m}$ 이하로 조밀하면서, 내플라즈마성이 우수한 소결체를 얻 을 수 있었다. $\mathrm{BN}$ 첨가에 의해 소결체의 미세구조에서 기공들이 관찰되었으며, 기존의 순수 $\mathrm{Y}_{2} \mathrm{O}_{3}$ 의 소결시간 $(30 \mathrm{hrs})$ 에 비해, 본 연구에서 제작한 $\mathrm{Y}_{2} \mathrm{O}_{3}$-BN 복합체의 경우, 상대적으로 짧은 소결시간 $(4 \mathrm{hrs})$ 동안 기공소멸이 충분히 이루어지지 못한 것으로 추정된다. 내플라즈마 특성 평가를 위해 본 연구에서 제조된 시편을 이용하여 건식 에칭을 통해 평가하였다. Table 6 은 $\mathrm{BN}$ 첨가 $\mathrm{Y}_{2} \mathrm{O}_{3}$ 소결체의 건식에칭 테스트 이후 분석 자료로서 $\mathrm{BN}$ 첨가 된 $\mathrm{Y}_{2} \mathrm{O}_{3}$ 복합체는 $\mathrm{BN}$ 첨가량에 따라 식각 깊이(Edge depth)가 감소하는 경향을 나타냈다. 내플라즈마 세라믹

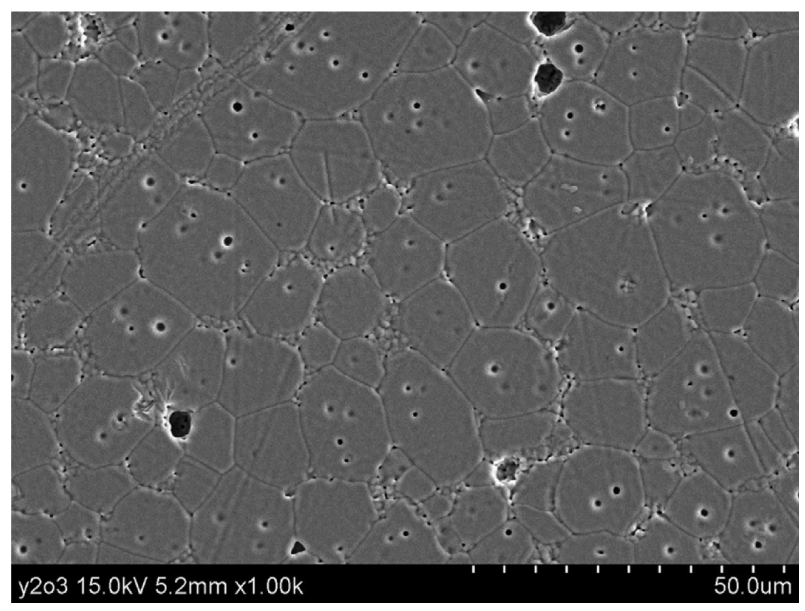

Fig. 4. Microstructure of $\mathrm{Y}_{2} \mathrm{O}_{3}-0.25 \mathrm{wt} \% \mathrm{BN}$ composites $\left(1600^{\circ} \mathrm{C}\right.$, $4 \mathrm{hrs})$. 
Table 6

Results of dry etching test of $\mathrm{Y}_{2} \mathrm{O}_{3}$ - $\mathrm{BN}$ composites with forming pressure and sintering time

\begin{tabular}{|c|c|c|c|c|c|c|c|}
\hline \multirow{2}{*}{ Specimen } & \multirow{2}{*}{$\begin{array}{l}\text { Edge depth-1 } \\
(\mathrm{mm})\end{array}$} & \multirow{2}{*}{$\begin{array}{l}\text { Edge depth-2 } \\
(\mathrm{mm})\end{array}$} & \multirow{2}{*}{$\begin{array}{l}\text { Edge depth-3 } \\
(\mathrm{mm})\end{array}$} & \multicolumn{4}{|c|}{ Test condition } \\
\hline & & & & Temp. $\left({ }^{\circ} \mathrm{C}\right)$ & Duration & Forming pressure (ton) & $\mathrm{BN}$ content $(\%)$ \\
\hline I 3 & 13.525 & 6.893 & 7.977 & 1600 & $4 \mathrm{hrs}$ & 1.5 & 0.25 \\
\hline K 3 & 12.775 & 11.156 & 5.071 & 1600 & 4hrs & 1 & 0.5 \\
\hline N 3 & 12.681 & 10.447 & 5.940 & 1600 & $4 \mathrm{hrs}$ & 1 & 1 \\
\hline Q 3 & 10.041 & 8.204 & 7.379 & 1600 & $4 \mathrm{hrs}$ & 1 & 2 \\
\hline $\mathrm{Y}_{2} \mathrm{O}_{3}$ & 6.268 & 6.518 & 6.392 & 1650 & $30 \mathrm{hrs}$ & 1.5 & - \\
\hline $\mathrm{Al}_{2} \mathrm{O}_{3}$ & 25.322 & 30.912 & 30.281 & - & - & - & - \\
\hline
\end{tabular}

소재로 널리 쓰이는 $\mathrm{Al}_{2} \mathrm{O}_{3}$ 보다 다소 우수한 내플라즈마 특성을 보였으며, 고순도 $\mathrm{Y}_{2} \mathrm{O}_{3}$ 소결체에 비해서는 내플 라즈마 특성이 다소 낮은 경향을 나타내었다. $\mathrm{BN}$ 이 도 입된 $\mathrm{Y}_{2} \mathrm{O}_{3}-\mathrm{BN}$ 복합체는 순수한 $\mathrm{Y}_{2} \mathrm{O}_{3}$ 에 비해서, 소결온 도 저하 및 상대적으로 짧은 소결시간 동안 소결이 비교 적 용이하게 이루어졌으며, 소결밀도 및 기계적 물성, 내 플라즈마 특성이 크게 저하되지 않는 경향을 나타냈다.

\section{4. 결 론}

본 연구에서 제작된 $\mathrm{Y}_{2} \mathrm{O}_{3}-\mathrm{BN}$ 복합체는, $\mathrm{BN}$ 을 0.25 $\mathrm{wt} \%$ 첨가하여, $1600^{\circ} \mathrm{C}$ 에서 소결 시, 굽힘강도, 절연저항 등의 특성이 비교적 우수한 것으로 나타났다. $\mathrm{Y}_{2} \mathrm{O}_{3}-\mathrm{BN}$ 복합체의 소결은 $1,500 \mathrm{kgf} / \mathrm{cm}^{2}$ 압력 조건에서 $1600^{\circ} \mathrm{C}$ 까지 온도가 상승하면서 소결밀도가 $4.9 \mathrm{~g} / \mathrm{cm}^{2}$ 까지 상승 하였고 꺽임강도, 절연저항, 비커스경도, 열팽창계수은 $1550^{\circ} \mathrm{C}$ 이상이면 고순도 $\mathrm{Y}_{2} \mathrm{O}_{3}$ 소결체의 특성에 근접한 $\mathrm{Y}_{2} \mathrm{O}_{3}-\mathrm{BN}$ 복합체를 얻을 수 있었다. 본 연구에서 얻어진, $\mathrm{Y}_{2} \mathrm{O}_{3}-\mathrm{BN}$ 세라믹 복합체는 순수 $\mathrm{Y}_{2} \mathrm{O}_{3}$ 에 비해서는 식각 률이 다소 높은 수치를 나타내었지만, $\mathrm{Al}_{2} \mathrm{O}_{3}$ 에 비해서는 비교적 우수한 내플라즈마 특성을 나타내었다.

\section{감사의 긑}

“이 논문은 2013년도 정부(교육부)의 재원으로 한국연 구재단의 지원을 받아 수행된 기초연구사업임(NRF2013R1A1A2065604)".

“이 논문은 2010 학년도 조선대학교 학술연구비의 지원 을 받아 연구되었음".

\section{References}

[ 1 ] M. Kodo, K. Soga, H. Yoshida and T. Yamamoto, "Doping effect of divalent cations on sintering of polycrystalline yttria", J. Eur. Ceram. Soc. 30(13) (2010) 2741.
[2] R. Chaima, A. Shlayer and C. Estournes, "Densification of nanocrystalline $\mathrm{Y}_{2} \mathrm{O}_{3}$ ceramic powder by spark plasma sintering", J. Eur. Ceram. Soc. 29(1) (2009) 91.

[3] L. Ana, A. Ito and T. Goto, "Transparent yttria produced by spark plasma sintering at moderate temperature and pressure profiles", J. Eur. Ceram. Soc. 32(5) (2012) 1035.

[4] Y. Kobayashi, "Current status and needs in the future of ceramics used for semiconductor production equipment", p.17, Osaka, Japan, July, 2005, The 37th Seminar on High Temperature Ceramics (2005).

[ 5 ] N. Ito, T. Moriya, F. Uesugi, M. Matsumoto, S. Liu and Y. Kitayama, "Reduction of particle contamination in plasma-etching equipment by dehydration of chamber wall", Jpn. J. Appl. Phys., PartI 47(5) (2008) 3630.

[6] H. Di, Z. Yanchun, S. Xudong, L. Xiaodon and L. Shaohong, "Preparation of transparent $\mathrm{Y}_{2} \mathrm{O}_{3}$ ceramic by slip casting and vacuum sintering", J. Rare Earth 30(1) (2012) 57.

[7] X. Qin, H. Yang, G. Zhou, D. Luo, J. Zhang, S. Wang and J. Mad, "Synthesis of submicron-sized spherical $\mathrm{Y}_{2} \mathrm{O}_{3}$ powder for transparent YAG ceramics", Mater. Res. Bull. 46(2) (2011) 170.

[8] P. Duran, J. Tartaj and C. Moure, "Sintering behaviour of $\mathrm{Y}_{2} \mathrm{O}_{3}$ powders prepared by the polymer complex solution method", Ceram Inter. 28(7) (2002) 791.

[9] J.H. Han, "Synthesis of sinter-active $\mathrm{Y}_{2} \mathrm{O}_{3}$ powders using Urea", J. Kor. Ceram. Soc. 34(12) (1997) 1247.

[10] P. Merkert, H. Hahn and J. Rodel, "Sintering behavior of nanocrystalline $\mathrm{Y}_{2} \mathrm{O}_{3}$ ", Nanostructured Mater. 12(5-8) (1999) 701.

[11] J. Luo, Z. Zhong and J. Xu, "Yttrium oxide transparent ceramics by low-temperature microwave sintering", Mater. Res. Bull. 47(12) (2012) 4283.

[12] J. Iwasawa, R. Nishimizu, M. Tokita, M. Kiyohara and $\mathrm{K}$. Uematsu, "Plasma resistance dense yttrium oxide film prepared by aerosol deposition process", J. Am. Ceram. Soc. 90(8) (2007) 2327.

[13] J.S. Choi, T. Nakayama and W.T. Bae, "Plasma resistance evaluation and characteristics of Yttria ceramics sintered by using calcination Yttria", J. Kor. Ceram. Soc. 50(5) (2013) 348.

[14] X. Chenga, C. Yuana, N.R. Greena and P.A. Withey, "Sintering mechanisms of Yttria with different additives", Ceram Inter. 39(5) (2013) 4791.

[15] I. Takayuki and K. Masakatsu, "Sintered yttria, anticorrosion member and process for producing the same", Korean patent, Registration No.1009201040000 (2009). 